\title{
Co-tolerance to zinc and copper of the soil nitrifying community and its relationship with the community structure
}

\author{
Stefan Ruyters ${ }^{*}$, Jelle Mertens, Dirk Springael and Erik Smolders \\ Address: Department of Earth and Environmental Sciences, Division of Soil and Water \\ Management, K.U.Leuven, Kasteelpark Arenberg 20, 3001 Heverlee, Belgium \\ *Corresponding author \\ email address: struyters@yahoo.com
}




\section{Abstract}

Soil microbial communities can develop trace metal tolerance upon soil contamination with corresponding metals. A few studies have reported co-tolerance in such cases, i.e. tolerance to other metals than those to which the microbial community had been exposed to. This study was set-up to test for co-tolerance of nitrifying communities to zinc $(\mathrm{Zn})$ and copper $(\mathrm{Cu})$ and to relate tolerances to shifts in community structure using amoA AOB (ammonia oxidizing bacteria) DGGE. Seven sets of soils, each representing a $\mathrm{Cu}$ or $\mathrm{Zn}$ contamination gradient were sampled from four locations. At two locations, both $\mathrm{Cu}$ and $\mathrm{Zn}$ had been added as single contaminants. Increased $\mathrm{Zn}$ and $\mathrm{Cu}$ tolerance of the nitrifying communities was consistently observed in response to corresponding soil contamination. Co-tolerance to $\mathrm{Zn}$ was obtained in two of the three $\mathrm{Cu}$ gradients and that to $\mathrm{Cu}$ in one of the four $\mathrm{Zn}$ gradients. DGGE analysis and sequencing showed that contamination with either $\mathrm{Zn}$ or $\mathrm{Cu}$ selected for identical AOB phylotypes in soils at one location but not at the other location. The nitrifying community structures in soils from different locations did not become more similar upon $\mathrm{Zn}$ exposure than those in corresponding uncontaminated soils. Hence, trace metal tolerance development was not due to the emergence of specific AOB phylotypes, but due to the emergence of different AOB phylotypes bearing tolerance mechanisms for $\mathrm{Zn}, \mathrm{Cu}$ or both metals.

\section{Introduction}

Previous studies showed that trace metal contamination decreased the microbial function on the short term. EC50 values for nitrification range from 150-1200 mg kg-1 depending on the soil for both $\mathrm{Zn}$ and $\mathrm{Cu}$ (Smolders et al., 2003, Oorts et al., 2006). These EC50 values are close to the background values of $\mathrm{Zn}\left(10-300 \mathrm{mg} \mathrm{kg}^{-1}\right)$ and $\mathrm{Cu}\left(1-239 \mathrm{mg} \mathrm{kg}^{-1}\right)$ naturally occurring in soil. However, it is well known that the soil microbial community function may recover from 
increased trace metal concentrations by tolerance development of the microbial community (Giller et al., 1998). This development of trace metal community tolerance is attributed to the extinction of sensitive populations and the selection and proliferation of metal tolerant populations (Diáz-Raviña and Bååth, 1996) resulting in a changed community structure and a recovery of the soil microbial function (Frostegård et al., 1996; Bååth et al., 1998; Witter et al., 2000). This has been shown in $\mathrm{Zn}$ and $\mathrm{Cu}$ contaminated soils for the general microbial community as well as for specific groups such as the nitrifying community (Mertens et al., 2006; Mertens et al., 2010; Ruyters et al., 2010).

Trace metal tolerance mechanisms are present in nearly all bacterial phyla due to horizontal transfer of chromosomal or plasmid encoded mobile genetic elements (Bruins et al., 2000) and are obviously also found in soil bacteria (Ryan et al., 2005). An important group of resistance mechanisms are P-type ATPases which are efflux systems transporting cations over the cell membrane, e.g. the czc system removing $\mathrm{Cd}^{2+}, \mathrm{Zn}^{2+}$ and $\mathrm{Co}^{2+}$ (Nies, 1999). Park and Ely (2008) determined 27 genes that were up-regulated by $\mathrm{Zn}$ in Nitrosomonas europaea. These included for example mercury resistance genes and inorganic ion transport genes. Thirty genes were downregulated, e.g. amino acid transporter genes.

Coping with stress is energy demanding and therefore a tolerant microbial community may be more vulnerable to additional stress as shown by Tobor-Kaplon et al. (2006a) in Zn contaminated soils. Alternatively, a tolerant community might better cope with other stresses than a nontolerant community if the additional stress occurs through a similar mechanism as the first one (Tobor-Kaplon et al., 2006b). An example of such co-tolerance process is the development of tolerance to other trace metals than those to which the microbial community had been exposed to due to, e.g., similar physiological tolerance mechanisms (Bruins et al., 2000). Only few studies 
are available on the occurrence of co-tolerance in microbial communities for multiple trace metals in soil. Using the thymidine incorporation technique, Diáz-Raviña et al. (1994) showed that soil contaminated with either $\mathrm{Cd}, \mathrm{Ni}, \mathrm{Pb}, \mathrm{Zn}$ or $\mathrm{Cu}$ did not only induce tolerance to the corresponding metal, but also to other trace metals. Rusk et al. (2004) showed that the soil nitrifying community in $\mathrm{Pb}$ contaminated soils also developed co-tolerance to $\mathrm{Zn}$ and in $\mathrm{Zn}$ contaminated soils to $\mathrm{Pb}$. Co-tolerance to multiple metals might be due to non-specific efflux systems, intracellular protein binding (e.g. metallothioneins for $\mathrm{Cu}^{2+}$ and $\mathrm{Zn}^{2+}$ ) or to closely linked plasmid or genomic gene clusters encoding different metal tolerance mechanisms. For example, plasmid pMOL30 isolated from Alcaligenes eutrophus, encodes for the czc system and Cu tolerance (Mergeay, 1991).

Little is known about the relation between the development of co-tolerance and changes of the microbial community. The general objective of this study was to determine co-tolerance of the nitrifying community in soil to zinc $(\mathrm{Zn})$ and copper $(\mathrm{Cu})$ in relation to $\mathrm{Zn}$ and $\mathrm{Cu}$ exposure scenarios and to analyze the effects of $\mathrm{Zn}$ and $\mathrm{Cu}$ on the microbial community structure. We assessed if changes of the soil nitrifying community were similar in two soils contaminated with either $\mathrm{Zn}$ or $\mathrm{Cu}$, i.e. starting with the same community composition and structure, but contaminated with a different metal. In addition, we questioned whether the bacterial nitrifying community that is metal tolerant would converge to a similar community structure in different soils that inherently have a different native community composition and structure. Only the Ammonia Oxidizing Bacteria (AOB) were considered in the community analysis, since previous studies showed that Ammonia Oxidizing Archaea (AOA) play a minor role in recovery of the nitrification after Zn contamination (Mertens et al., 2009; Ruyters et al., 2010). It is unknown if the same is true for adaptation to $\mathrm{Cu}$ contamination. 


\section{Materials and methods}

\section{Soil sampling}

Eight sets of soils, each representing a $\mathrm{Zn}$ or $\mathrm{Cu}$ concentrations gradient or a corresponding pair of contaminated and uncontaminated (control) soil were collected at 4 different locations (Table 2). Major soil characteristics for the corresponding uncontaminated (control) soils are summarized in Table 1. Zinc contaminated soils from Zeveren (Zev-Zn-Field) (Belgium) and De Meern (DM-Zn-Field) (The Netherlands) were sampled in October 2009 in grassland transects towards a galvanized pylon. The Hygum soil set (Denmark) was sampled in June 2007 near a former wood treatment plant contaminated with $\mathrm{CuSO}_{4}$ over 80 years ago (Hy-Cu-Field). Other soil sets were derived from artificially contaminated sites or lab experiments. An uncontaminated Zeveren soil, sampled in June 2007, was artificially spiked with increasing doses of $\mathrm{ZnCl}_{2}$ (60$2500 \mathrm{mg} \mathrm{Zn} \mathrm{kg}{ }^{-1}$; Zev-Zn-Sp) (Ruyters et al., 2010) or 1 dose of $\mathrm{CuCl}_{2}$ (2400 mg Cu kg-1 $\mathrm{Zev}^{-}$ $\mathrm{Cu}-\mathrm{Sp}$ ) and had been incubated outside with free drainage for more than 2 years. The soil $\mathrm{pH}$ of Zev-Cu-Sp was lower than the soil $\mathrm{pH}$ of the control (4.7 vs. 5.5). Spalding soil (Australia) was artificially spiked with increasing concentrations of either $\mathrm{ZnSO}_{4}(\mathrm{Spal}-\mathrm{Zn}-\mathrm{Sp})$ or $\mathrm{CuSO}_{4}(\mathrm{Spal}-$ $\mathrm{Cu}-\mathrm{Sp}$ ) and incubated outside during 4 years (Broos et al., 2007). Soil pH decreased in Spal-CuSp 2800 from 5.5 in the control soil to 4.8 in the $\mathrm{Cu}$ spiked soil. All soils were sieved $(<4 \mathrm{~mm})$ and stored fresh in plastic bags at $4{ }^{\circ} \mathrm{C}$ (soils from Zeveren, De Meern, Hygum) or were air dried stored at room temperature (soils from Spalding) pending analyses. Prior to testing metal tolerances and DNA extraction, soils were remoistened and aerobically incubated for 2 weeks at $25{ }^{\circ} \mathrm{C}$ except for the freshly sampled $\mathrm{Zn}$ contaminated soils from Zeveren and De Meern (1 week incubation). 
Table 1: Background $\mathrm{Zn}$ and $\mathrm{Cu}$ concentrations and selected properties of the uncontaminated soils from the four locations.

\begin{tabular}{lcccccc}
\hline Site & $\begin{array}{c}\text { Background }\left(\mathbf{m g ~ k g}^{-\mathbf{1}}\right) \\
\mathbf{Z n}\end{array}$ & $\mathbf{C u}$ & $\mathbf{p H}{ }^{(\mathbf{a})}$ & $\begin{array}{c}\mathbf{C}_{\mathbf{o r g}}{ }^{(\mathbf{a})} \\
(\mathbf{\%})\end{array}$ & $\begin{array}{c}\mathbf{C E C}^{(\mathbf{a})} \\
\left(\mathbf{c m o l ~ k g}^{\mathbf{1}}\right)\end{array}$ & Sampling date \\
\hline Zeveren & 50 & 15 & 5.5 & 3.5 & 21.1 & June 2007 \\
De Meern & 140 & 60 & 5.0 & 10.2 & 29.6 & October 2009 \\
Spalding & 60 & 80 & 5.5 & 2.2 & 15.9 & 2009 \\
Hygum & 40 & 20 & 5.8 & 2.1 & 6.7 & June 2007 \\
\hline
\end{tabular}

(a) $\mathrm{pH}, \mathrm{C}_{\text {org }}$ and CEC were determined as described by Smolders et al. (2004)

Table 2: Overview of the soil sets selected for $\mathrm{Zn}$ or $\mathrm{Cu}$ tolerance testing either contaminated with $\mathrm{Zn}$ or with $\mathrm{Cu}$. A distinction is made between the contamination type: gradual contaminated over time in the field ('field') and long term aged after artificial spiking with metal salts ('Sp'). As such, seven sets are distinguished differing in location, trace metal or contamination type.

\begin{tabular}{|c|c|c|c|c|}
\hline Site & Soil Set & $\mathrm{Zn}\left(\mathrm{mg} \mathrm{kg}^{-1}\right)$ & $\mathrm{Cu}\left(\mathrm{mg} \mathrm{kg}^{-1}\right)$ & $\begin{array}{c}\text { Exposure time } \\
\text { (years) }\end{array}$ \\
\hline Zeveren & Zev-Zn-Field & 370 & bg & $>10$ \\
\hline \multirow[t]{7}{*}{ Belgium } & & $800^{\text {(a) }}$ & bg & $>10$ \\
\hline & & $1200^{\text {(a) }}$ & bg & $>10$ \\
\hline & Zev-Zn-Sp & 100 & bg & 2 \\
\hline & & 700 & bg & 2 \\
\hline & & 1300 & bg & 2 \\
\hline & & $2500^{\text {(a) }}$ & bg & 2 \\
\hline & $\mathrm{Zev}-\mathrm{Cu}-\mathrm{Sp}$ & bg & $2400^{\text {(a) }}$ & 2 \\
\hline Spalding & Spal-Zn-Sp & $1850^{\text {(a) }}$ & bg & 3 \\
\hline \multirow[t]{4}{*}{ Australia } & Spal-Cu-Sp & bg & 475 & 2 \\
\hline & & bg & 875 & 2 \\
\hline & & bg & 1850 & 2 \\
\hline & & bg & $2800^{\text {(a) }}$ & 4 \\
\hline De Meern & DM-Zn-Field & 600 & bg & $>10$ \\
\hline \multirow{3}{*}{\multicolumn{2}{|c|}{ The Netherlands }} & 1000 & bg & $>10$ \\
\hline & & 1700 & bg & $>10$ \\
\hline & & $4000^{(\mathrm{a})}$ & bg & $>10$ \\
\hline Hygum & Hy-Cu-Field & bg & 140 & $>80$ \\
\hline \multirow[t]{2}{*}{ Denmark } & & bg & 400 & $>80$ \\
\hline & & bg & $1500^{\text {(a) }}$ & $>80$ \\
\hline
\end{tabular}

(a) Soils were selected for co-tolerance testing

bg: Background concentration as given in Table 1 


\section{Trace metal tolerance}

Zinc or $\mathrm{Cu}$ tolerance of the soil nitrifying community was determined using the spike-on-spike assay described by Mertens et al. (2006). Briefly, $\mathrm{ZnCl}_{2}$ or $\mathrm{CuCl}_{2}\left(50 \mathrm{mg} \mathrm{ml}^{-1}\right)$ was added to soil samples suspended in $\mathrm{CaCl}_{2}$ 0.01 $\mathrm{M}$ (1:10 solid:liquid ratio) - these suspensions mimic an extraction of the soil microbial community - to final concentrations of 0 (in duplicate), 15, 30, 75, 150, 300 and $500 \mathrm{mg}$ metal added $\mathrm{l}^{-1}$. Ammonium chloride solution $\left(10 \mathrm{mg} \mathrm{ml}^{-1}\right)$ was added to a final concentration of $10 \mathrm{mg} \mathrm{NH}_{4}{ }^{+}-\mathrm{N}^{-1}$. The $\mathrm{pH}$ in suspension was adjusted immediately after $\mathrm{N}$ addition and daily during the 3 -day test to the $\mathrm{pH}$ of the corresponding control soil $( \pm 0.1)$ using $0.1 \mathrm{M} \mathrm{NaOH}$ or $\mathrm{HCl}$ if required. Nitrate concentrations were measured colorimetrically in a $1 \mathrm{M}$ $\mathrm{KCl}$ soil extract (SA 40, Skalar, The Netherlands) at the start of the experiment and after 3 days incubation at $20 \pm 1{ }^{\circ} \mathrm{C}$ with head over end agitation (28 rpm). The Potential Nitrification Rate (PNR) was calculated as the rate of increase in nitrate concentration per unit of soil dry weight over time ( $\mathrm{mg} \mathrm{NO}_{3}^{-}-\mathrm{N} \mathrm{kg}^{-1} \mathrm{~d}^{-1}$ ). The PNR in suspension was related to $\mathrm{Zn}$ concentrations in the $\mathrm{CaCl}_{2}$ soil extract. The metal concentrations in the $\mathrm{CaCl}_{2} 0.01 \mathrm{M}$ extract were measured at day 3 after centrifugation in the filtered and acidified supernatant (3000 g, $15 \mathrm{~min}$ ) with ICP-OES (Perkin Elmer Optima 3300 DV, Norwalk, CT, USA). Metal concentrations of the control suspensions (no extra metal added) increased with increasing total soil metal concentration in the soil sets and this increase was more pronounced in the spiked soil sets. Dissolved organic carbon (DOC) concentrations were measured in a filtered $(0.45 \mu \mathrm{m})$ soil extract (catalytic combustion with IR detection; Multi N/C 2100, AnalyticJena). The $\mathrm{Zn}$ and $\mathrm{Cu}$ speciation in all suspensions was calculated using the Windermere Humic Acid Model (WHAM) v.6.0.13 (Tipping, 1998). Input data were the metal concentration, $\mathrm{NH}_{4}{ }^{+}$and $\mathrm{Ca}^{2+}$ concentration, the corresponding $\mathrm{Cl}^{-}$ concentration in solution, solution $\mathrm{pH}$ and reactive dissolved organic matter (DOM). Reactive 
DOM was calculated by multiplying the DOC concentration by 1.3, assuming that DOM consists of $50 \%$ DOC and that $65 \%$ of the DOM is reactive as fulvic acid (Weng et al., 2002). Doseresponse curves, based on the Potential Nitrification Rate values and the metal free ion concentrations, were fitted by log-logistic modeling (Doelman and Haanstra, 1989) using the Marquardt method (proc NLIN, SAS ${ }^{\circledR} 9.2$; NC, USA). Trace metal tolerance was expressed as the free $\mathrm{Zn}^{2+}$ or $\mathrm{Cu}^{2+}$ concentrations at which the PNR was $50 \%$ reduced compared to the control treatment (EC50) and are derived from the dose-response curves.

\section{DNA extraction and amoA AOB profiling}

Soil DNA was extracted and purified with the MO BIO Powersoil DNA Isolation Kit according to the manufacturer's protocol (MO BIO laboratories, California, USA). PCR amplification of AOB amoA gene fragments using primers GC-amoA-1F* and amoA-2R (Rotthauwe et al., 1997; Stephen et al., 1998) was performed as described by Mertens et al. (2009). The PCR product size and integrity was checked using standard agarose gel electrophoresis. Denaturing Gradient Gel Electrophoresis (DGGE; Ingeny, Goes, The Netherlands) profiling analysis of the amoA gene fragments was performed using $6 \%$ polyacrylamide gels with a linear gradient of $40-60 \%$ as described by Mertens et al. (2006).

\section{Cloning and sequencing}

PCR products obtained from selected soil samples (Spalding Zn 1850 and Spalding Cu 2800; Zeveren Zn 2500 and Zeveren $\mathrm{Cu}$ 2400) were cloned into the plasmid vector $\mathrm{pCR}^{\circledR} 2.1-\mathrm{TOPO}^{\circledR}$, using the TOPO TA cloning kit according to the manufacturer's protocol (Invitrogen, Merelbeke, Belgium). Transformants were analyzed for the presence of the amoA gene by PCR amplification using the amoA primers described above. The obtained PCR product was purified with the 
QIAquick PCR purification kit (Qiagen). Sequencing reactions were performed with the BigDye Terminator Cycle Sequencing Ready Reaction kit using both the GC-amoA-1F* and amoA-2R primers and analyzed with the ABI 3100/3130 DNA-Sequencer (Applied Biosystems).

\section{Data analysis}

Metal tolerance is defined as the EC50 value of the fitted dose-response curve (mg trace metal ${ }^{-1}$ suspension). Significantly increased EC50 values compared to those of the corresponding control soil represent significant increased metal tolerance and were detected by a one-sided t-test $(\mathrm{p}<$ 0.05). Metal tolerances (EC50 values) were not compared among soils of different sites, since the solution based thresholds are also affected by $\mathrm{pH}$ and soil $\mathrm{pH}$ values differed between soils. Pairwise comparison of DGGE profiles was based on the Pearson product-moment correlation coefficient using the GelCompar II software 3.5 (Applied Maths, Sint-Martens-Latem, Belgium). Negative correlation values are trimmed to zero, because they do not have any biological meaning. Correlations are expressed as percentage values and are frequently used as similarity coefficients comparing DGGE profiles (Fromin et al., 2002). Preliminary DGGE gels showed at least $90 \%$ similarity between replicate samples (Ruyters et al., 2010 for the Zev-Zn-Sp set, Mertens et al., 2010 for the Spal-Cu-Sp and Hy-Cu-Field sets and data not shown for the other sets) and therefore only one replicate was loaded. The community structure data were reduced to a 2 dimensional space by nMDS ordination based on the Bray-Curtis distance measure (PC-ORD v5) (Ramette, 2007). ANOVA was performed on both ordination axes to test if the amoA AOB DGGE profiles of different soils converged when becoming $\mathrm{Zn}$ tolerant. Increased $\mathrm{Zn}$ tolerance was classified as a nominal factor. Sequences were aligned with MEGA version 5.0 (Kumar et al., 2004) based on the CLUSTALW algorithm (Thompson et al., 1994) using default parameters. A phylogenetic tree was generated with MEGA 5.0 with the obtained sequences using the 
neighbor-joining algorithm. $\mathrm{Cu}$ tolerance of the nitrifying community of the $\mathrm{Cu}$ contaminated Spalding and Hygum soil sets (Spal-Cu-Sp and Hy-Cu-Field - Mertens et al., 2010) and Zn tolerance of the nitrifying community of the Zn contaminated Spalding sets (Spal-Zn-Sp 1850 Mertens et al., 2009) were determined previously, and values were adopted from those studies. The amoA DGGE profiling of those soils was repeated in this study.

\section{Results}

\section{Metal tolerance and co-tolerance}

Table 3 gives an overview of the $\mathrm{Zn}$ and $\mathrm{Cu}$ tolerances in all soil sets. The $\mathrm{Zn}$ EC50 values ( $\mathrm{Zn}$ tolerance) increases in each of the $4 \mathrm{Zn}$ sets and tolerance increased with increasing soil $\mathrm{Zn}$. In the Zeveren soil, artificial $\mathrm{Zn}$ contamination (Zev-Zn-Sp) followed by more than 2 years incubation increased $\mathrm{Zn}$ tolerance (Table 3). Spiking followed by 2 years incubation also increased Zn tolerance in the Spalding soil sets (Spal-Zn-Sp) (Table 3) as previously shown by Mertens et al. (2009). Five Zn contaminated soils which showed significantly increased Zn tolerance and the corresponding control soils were selected for $\mathrm{Cu}$ tolerance testing. Only the $\mathrm{Zn}$ tolerant community of the Zeveren soil (Zev-Zn-Sp, $2500 \mathrm{mg} \mathrm{Zn} \mathrm{kg}^{-1}$ ) showed increased $\mathrm{Cu}$ tolerance compared to the corresponding control soil community (Table 3).

Copper contamination increased $\mathrm{Cu}$ tolerance in all $\mathrm{Cu}$ contaminated sets of this study. (Table 3). Increased $\mathrm{Cu}$ tolerance of $\mathrm{Cu}$ contaminated soils was previously reported by Mertens et al. (2010) for the artificially $\mathrm{Cu}$ contaminated Spalding sets (Spal-Cu-Sp) and the field contaminated Hygum sets (Hy-Cu-Field) (Table 3). Two of the three soils with significantly increased $\mathrm{Cu}$ tolerance also showed increased Zn tolerance (Zev-Cu-Sp 2400 mg Cu kg ${ }^{-1}$ en Spal-Cu-Sp 2800 mg Cu kg-1 ; Table 3). 
Table 3: $\mathrm{Zn}$ tolerances $\left(\mathrm{EC50}, \mathrm{mM} \mathrm{Zn}^{2+}\right.$ ) and $\mathrm{Cu}$ tolerances $\left(\mathrm{EC50}, \mu \mathrm{M} \mathrm{Cu}^{2+}\right.$ ) of the nitrifying communities in the soil series. Significant increased $\mathrm{EC50}$ values $(p<0.05)$ compared with the EC50 of the corresponding control soil are in bold and show increased tolerance to the soil contamination. EC50 values which denote co-tolerance are in bold and underlined.

\begin{tabular}{|c|c|c|c|c|c|c|c|c|c|}
\hline & \multicolumn{4}{|c|}{ Zeveren } & \multicolumn{5}{|c|}{ Spalding } \\
\hline & \multicolumn{2}{|c|}{ Metal concentration } & \multicolumn{2}{|c|}{ EC50 } & & \multicolumn{2}{|c|}{ Metal concentration } & \multicolumn{2}{|c|}{ EC50 } \\
\hline & $\mathrm{Zn}\left(\mathrm{mg} \mathrm{kg}^{-1}\right)$ & $\mathrm{Cu}\left(\mathrm{mg} \mathrm{kg}^{-1}\right)$ & $\mathrm{Zn}^{2+}(\mathrm{mM})$ & $\mathrm{Cu}^{2+}(\mu \mathrm{M})$ & & $\mathrm{Zn}\left(\mathrm{mg} \mathrm{kg}^{-1}\right)$ & $\mathrm{Cu}\left(\mathrm{mg} \mathrm{kg}^{-1}\right)$ & $\mathrm{Zn}^{2+}(\mathrm{mM})$ & $\mathrm{Cu}^{2+}(\mu \mathrm{M})$ \\
\hline control & 50 & 15 & 0.17 & 3.8 & control & 60 & 80 & 0.32 & $6.3^{(b)}$ \\
\hline Zev-Zn-Field & 370 & 15 & 0.43 & nd & Spal-Zn-Sp & 1850 & 80 & $>1.5^{(\mathrm{a})}$ & 0.79 \\
\hline Zev-Zn-Field & 800 & 15 & 1.7 & 8.7 & & & & & \\
\hline Zev-Zn-Field & 1200 & 15 & 0.73 & 3.3 & Spal-Cu-Sp & 60 & 475 & nd & $7.9^{(b)}$ \\
\hline Zev-Zn-Sp & 100 & 15 & 0.22 & nd & $\begin{array}{l}\text { Spal-Cu-Sp } \\
\text { Spal-Cu-Sp }\end{array}$ & $\begin{array}{l}60 \\
60\end{array}$ & $\begin{array}{c}875 \\
1850\end{array}$ & $\begin{array}{l}\text { nd } \\
\text { nd }\end{array}$ & $\begin{array}{c}19^{(b)} \\
441^{(b)}\end{array}$ \\
\hline Zev-Zn-Sp & 700 & 15 & 0.55 & nd & Spal-Cu-Sp & 60 & 2800 & $\underline{3.1}$ & $551^{(b)}$ \\
\hline Zev-Zn-Sp & 1300 & 15 & 0.63 & nd & & & & & \\
\hline Zev-Zn-Sp & 2500 & 15 & 1.7 & $\underline{19}$ & & & & & \\
\hline $\mathrm{Zev}-\mathrm{Cu}-\mathrm{Sp}$ & 50 & 2400 & 1.2 & 126 & & & & & \\
\hline
\end{tabular}




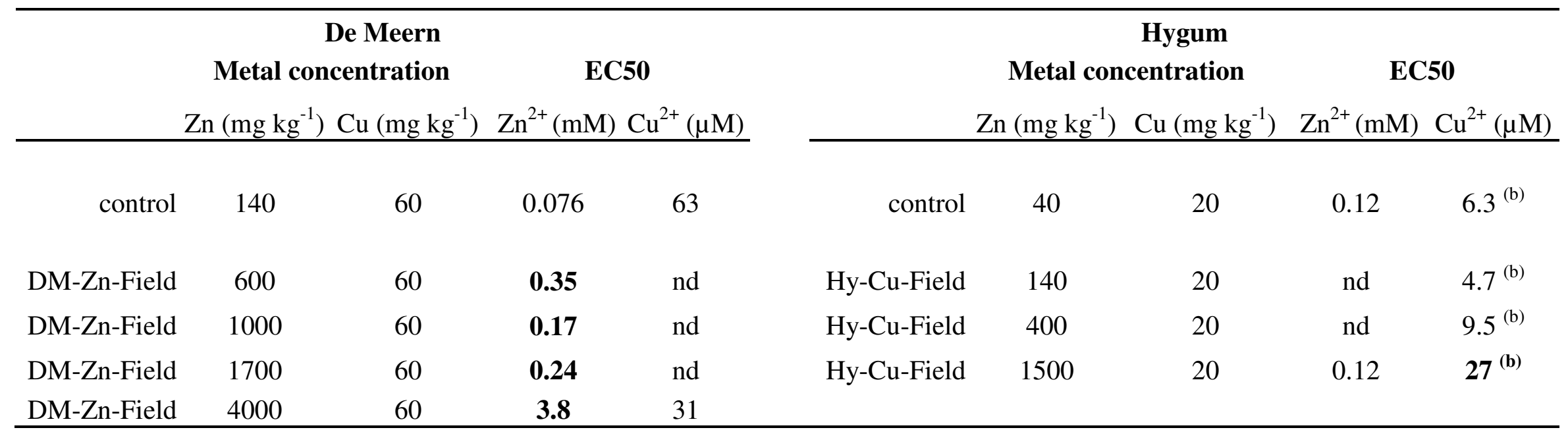

(a) Adopted from Mertens et al. (2009)

(b) Adopted from Mertens et al. (2010)

nd: not determined 
Nitrifying community structure

Changes of the soil nitrifying bacterial community structure between not contaminated and contaminated treatments were detected in all four $\mathrm{Zn}$ contaminated sets of soil. This was detected for both Zeveren soil sets (Zev-Zn-Field and Zev-Zn-Sp) in soils with $\mathrm{Zn}$ concentrations from $370 \mathrm{mg} \mathrm{Zn} \mathrm{kg}{ }^{-1}$ and $1300 \mathrm{mg} \mathrm{Zn} \mathrm{kg}{ }^{-1}$, respectively, and for the De Meern soil sets (DM-Zn-Field) from $1700 \mathrm{mg} \mathrm{Zn} \mathrm{kg-1} \mathrm{(Supplementary} \mathrm{Figure} \mathrm{1,} \mathrm{Panel} \mathrm{A).} \mathrm{Maximally} \mathrm{53-67 \%} \mathrm{pair-wise}$ similarity was observed between the corresponding control soil and those treatments. Zinc exposed soils from Spalding (Spal-Zn-Sp) also showed a distinctly different amoA DGGE profile compared with the corresponding control soil (15\% similarity).

Differences of the AOB community structure between the $\mathrm{Cu}$ contaminated soil and the corresponding control soil were observed in all $\mathrm{Cu}$ sets (Supplementary Figure 1, Panel B). The pair-wise similarity of the $\mathrm{AOB}$ community of the $\mathrm{Cu}$ contaminated soils with the corresponding control soil was low: 3\% for Zeveren $\mathrm{Cu}$ 2400, 20\% for Spalding Cu 2800 and 46\% for Hygum $\mathrm{Cu} 1500$.

In Figure 1 the AOB community profiles of all treatments are displayed after nMDS ordination with respect to their community similarity (Bray-Curtis). A shift of the community similarity relative to the corresponding control soil is observed within each contaminated soil sets showing an effect of trace metal contamination on the community structure (Figure 1). The amoA DGGE profiles of $\mathrm{Zn}$ contaminated soils from different locations did not cluster as can be seen on this graph, even if $\mathrm{Zn}$ concentrations are comparable. No effect of increased $\mathrm{Zn}$ tolerance on both ordination axes was detected $(\mathrm{p}>0.05)$ showing the development of different soil nitrifying and $\mathrm{Zn}$ tolerant communities at the different locations in response to $\mathrm{Zn}$ contamination. 


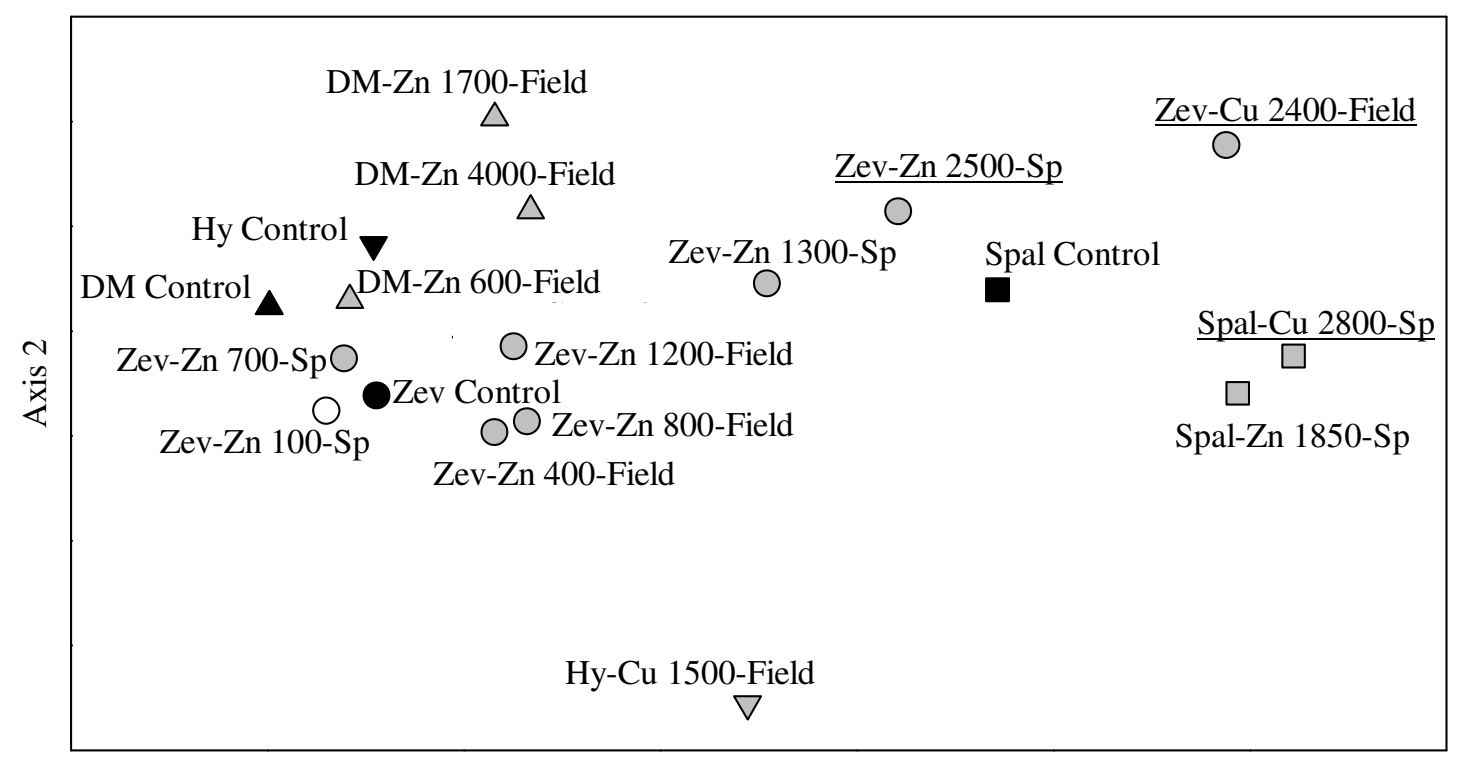

Axis 1

Figure 1: Graphical display of the amoA AOB DGGE profiles based on nMDS ordination (Bray Curtis). A shift of the amoA AOB DGGE profile of $\mathrm{Zn}$ or $\mathrm{Cu}$ contaminated soils compared to their respective control soil (black symbols) is observed. Gray shaded symbols indicate tolerance to the soil contamination. Underlined name tags indicate co-tolerance to $\mathrm{Zn}$ and $\mathrm{Cu}$. Zeveren: $\mathrm{O}$; Spalding: $\square$; De Meern: $\Delta$; Hygum: $\nabla$.

Co-tolerance was observed in the Zeveren soil artificially contaminated with $2500 \mathrm{mg} \mathrm{Zn} \mathrm{kg}^{-1}$, in the same soil artificially contaminated with $2400 \mathrm{mg} \mathrm{Cu} \mathrm{kg}^{-1}$ and in the Spalding soil contaminated with $2800 \mathrm{mg} \mathrm{Cu} \mathrm{kg}^{-1}$. Figure 2 compares the soil nitrifying communities in the Zeveren and Spalding soils contaminated with either metal. Pair-wise similarity between the nitrifying community structure of the $\mathrm{Zn}$ and $\mathrm{Cu}$ contaminated Spalding soils was 83\%. DNA sequences of the dominant band of both amoA DGGE profiles appeared to be identical (Figure 2 and Figure 3) (submitted to the GenBank database by Mertens et al. (2009) under accession number EU515200). The soil nitrifying communities of the Zeveren soil contaminated with either $\mathrm{Cu}$ or $\mathrm{Zn}$ showed $71 \%$ similarity, but dominant bands represented different sequences (see Figure 2 and Figure 3; submitted to the GenBank database under accession numbers HQ687667 (ZevZn-2500-Sp) and HQ687668 (Zev-Cu-2400-Sp). 


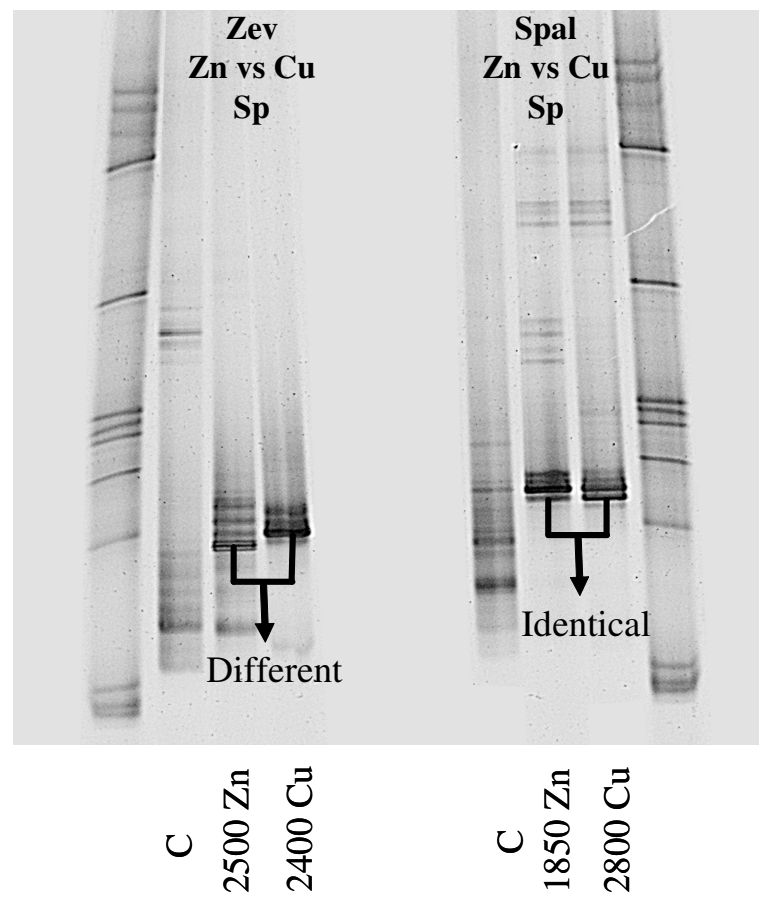

Figure 2: amoA AOB DGGE profile in the Zeveren and Spalding soil either contaminated with $\mathrm{Zn}$ or $\mathrm{Cu}$. Dominant bands have identical sequences in the Spalding soils, but different sequences in the Zeveren soils (Figure 3). Sampling series are indicated at the top. Control soils (designated with ' $\mathrm{C}$ ') and $\mathrm{Zn}$ or $\mathrm{Cu}$ concentrations ( $\mathrm{mg} \mathrm{kg}^{-1}$ ) are given under each DGGE profile.

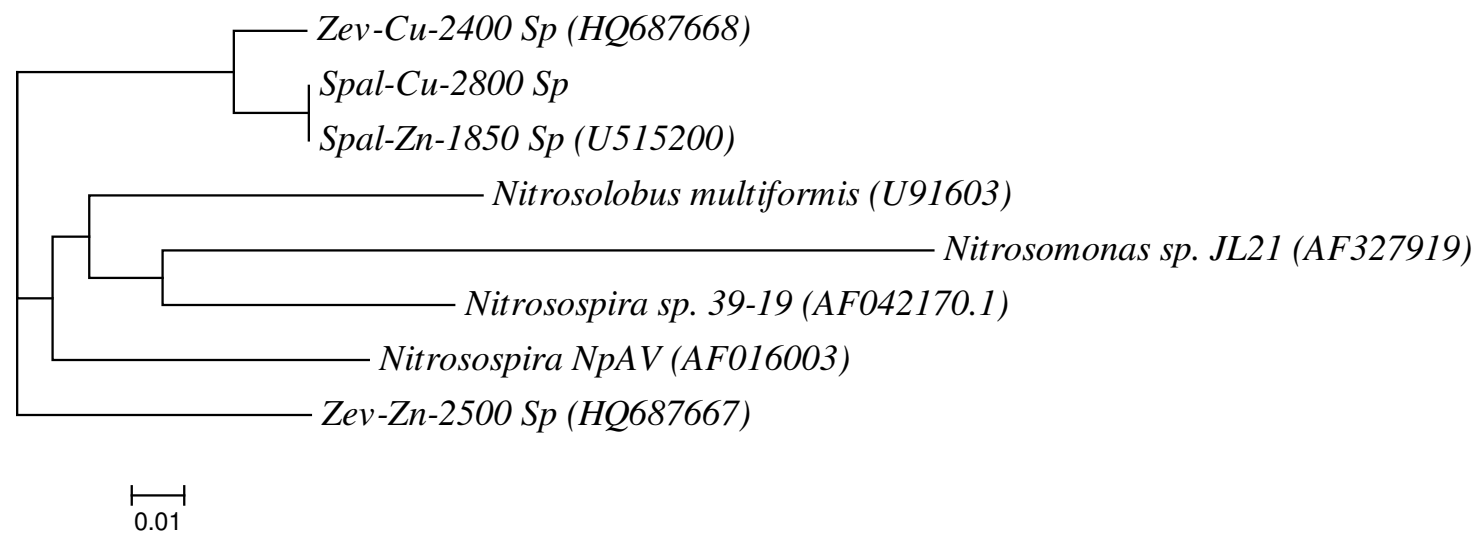

Figure 3: Phylogenetic tree (neighbor joining) of sequenced amoA fragments corresponding to the bands indicated in Figure 2. The sequence obtained from Spal-Cu-2800 Sp is identical to that of $\mathrm{Spal}-\mathrm{Zn}-1850 \mathrm{Sp}$, whereas the sequence obtained from $\mathrm{Zev}-\mathrm{Cu}-2400 \mathrm{Sp}$ is different from that of $\mathrm{Zev}-\mathrm{Zn}-2500 \mathrm{Sp}$. amo $\mathrm{A}$ fragment sequences from Nitrosospira, Nitrosomonas and Nitrosolobus spp. are given as reference. Accession numbers are given between brackets. 


\section{Discussion}

Increased trace metal tolerance of the microbial community in soil has previously been shown to develop on the long term and was reconfirmed here for $\mathrm{Zn}$ and $\mathrm{Cu}$. Development of tolerance at the community level is the net result of phenotypic changes, genotypic changes and the selection of tolerant species over sensitive species (Millward and Klerks, 2002). Exposure of the same soil nitrifying community to $\mathrm{Zn}$ or $\mathrm{Cu}$ resulted in the development of an increasingly similar community structure (Figure 2). This resemblance was striking for the Spalding soil community in which identical dominant phylotypes emerged upon $\mathrm{Zn}$ or $\mathrm{Cu}$ exposure. Resemblance increased to a lesser extent between the $\mathrm{Zn}$ and $\mathrm{Cu}$ contaminated Zeveren soil, as dominant phylotypes differed. The dominant phylotypes which emerged after metal exposure differed between both the Spalding and Zeveren soils. Based on changes of PLFA abundance after metal amendment (e.g. Zn, Pb, Cu, Ni, Cd) to forest mor layers Ákerblom et al. (2007) and Frostegård et al. (1993) similarly concluded that changes of the microbial community structure are independent of the type of metal added. In contrast, $\mathrm{Cu}$ contamination induced different changes of the community compared to $\mathrm{Zn}$ contamination in an arable soil (Frostegård et al., 1993).

Co-tolerance - tolerance of the soil bacterial community to other trace metals than the one to which the microbial community has been exposed to - to $\mathrm{Zn}$ and $\mathrm{Cu}$ was observed in three soil sets: in the artificially $\mathrm{Cu}$ contaminated Spalding and Zeveren soil sets, and in the artificially $\mathrm{Zn}$ contaminated Zeveren (not the Spalding) soil set. Nevertheless, co-tolerance to $\mathrm{Cu}$ was not

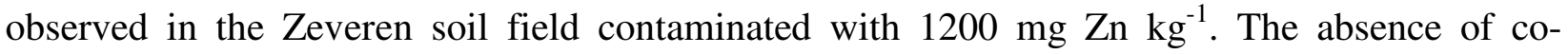
tolerance might be attributed to the lower total and $\mathrm{CaCl}_{2}$ extractable metal concentration in the field contaminated Zeveren soil (1200 $\mathrm{mg} \mathrm{Zn} \mathrm{kg}^{-1} ; 4 \mathrm{mg} \mathrm{Zn}^{2+} \mathrm{l}^{-1}$ ) compared to the artificially spiked soil (2500 mg Zn kg${ }^{-1} ; 23 \mathrm{mg} \mathrm{Zn}^{2+} 1^{-1}$ ). Diáz-Raviña et al. (1994) previously showed that 
the extent of co-tolerance to different metals is dependent on the metal concentration in soil. In addition, tolerance measurements in the present study are based on statistical methods on the microbial activity, including not only the presence of tolerant strains, but also their activity, which might explain that co-tolerance is not consistently observed. This might also explain the absence of $\mathrm{Cu}$ tolerance in the $\mathrm{Zn}$ contaminated Spalding soil sets despite the emergence of identical phylotypes in the co-tolerant $\mathrm{Cu}$ contaminated Spalding soil. The absence of cotolerance to $\mathrm{Zn}$ and $\mathrm{Cu}$ has been previously reported in $\mathrm{Cu}$ or $\mathrm{Zn}$ contaminated forest soils (Niklinska et al., 2006). Similarly to our study, Diáz-Raviña et al. (1994) observed more pronounced $\mathrm{Zn}$ co-tolerance in $\mathrm{Cu}$ contaminated soils than $\mathrm{Cu}$ co-tolerance in $\mathrm{Zn}$ contaminated soil.

Only AOB phylotypes bearing tolerance mechanisms for the metal they have been exposed to are considered to survive in soil after long term metal exposure. Since co-tolerance to $\mathrm{Zn}$ and $\mathrm{Cu}$ is observed in both the Zeveren soils spiked with $\mathrm{Zn}$ or $\mathrm{Cu}$, it is most likely that the identified dominant phylotypes bear tolerance mechanisms for both metals. Co-tolerance might be due to similar mechanisms for both trace metals (e.g. non-specific trace metal efflux systems) or due to closely linked gene clusters encoding specific tolerance mechanisms for $\mathrm{Zn}$ and $\mathrm{Cu}$. This study suggests that the development of co-tolerance is not necessarily associated with the selection of the same phylotypes after $\mathrm{Zn}$ or $\mathrm{Cu}$ exposure, but might also be due to the selection of different phylotypes bearing $\mathrm{Zn}$ and $\mathrm{Cu}$ tolerance mechanisms. Indeed, Ryan et al. (2005) showed the occurrence of bacterial strains tolerant to multiple trace metals $(\mathrm{Co}, \mathrm{As}, \mathrm{Ni}, \mathrm{Zn}$ and $\mathrm{Cu})$ in a multiple trace metal contaminated soil $\left(4.5 \mathrm{mg}^{-1} \mathrm{Zn}, 1.3 \mathrm{mg} \mathrm{l}^{-1} \mathrm{Cu}, 0.4 \mathrm{mg} \mathrm{l}^{-1} \mathrm{As}, 0.4 \mathrm{mg} \mathrm{l}^{-1} \mathrm{Cd}\right.$ and $4 \mu \mathrm{g} \mathrm{l}^{-1} \mathrm{Hg}$ ). In fact, only $4 \%$ of the isolated strains were tolerant to only 1 metal showing that co-tolerance is widespread among bacterial strains. 
The occurrence of trace metal tolerance of the soil bacterial community is commonly observed in different soils (Diáz-Raviña and Bååth, 1996; Almås et al., 2004) and has been shown previously for the soil nitrifying community in particular (Fait et al., 2006; Mertens et al., 2006; Mertens et al., 2010). We raised the question if a similar contamination event selects for the same tolerant nitrifying populations in soils of different origin with a different native community. The soil nitrifying bacterial community is a rather select group of $\beta$-Proteobacteria (Koops and Pommerening-Roser, 2001). Therefore, specific AOB phylotypes which are tolerant to metals might become dominant after a similar contamination event. In contrast, Mertens et al. (2009) suggested that $\mathrm{Zn}$ tolerance is widespread throughout the Nitrosospira lineage, which may imply a divergent development of a tolerant community across soils. Divergence might be explained by horizontal gene transfer of genes encoding for tolerance mechanisms. In the present study it can be seen from both the DGGE profiles (Supplementary Figure 1) and the ordination based on Bray-Curtis similarity (Figure 1) that the amoA AOB DGGE profiles did not converge to a similar community profile in response to $\mathrm{Zn}$ or $\mathrm{Cu}$ contamination or due to the development of $\mathrm{Zn}$ or $\mathrm{Cu}$ tolerance. For example, when comparing artificial contaminated soils from Zeveren and Spalding only $23 \%$ similarity based on the Pearson coefficient is observed in Zn tolerant soils. Apparently, trace metal tolerance development was not due to the emergence of specific AOB phylotypes, but due to the emergence of different AOB phylotypes bearing tolerance mechanisms for $\mathrm{Zn}, \mathrm{Cu}$ or both metals. This suggests that changes of the community structure upon trace metal contamination were determined by the initial community composition and structure and during exposure shaped by the type of metal and the dose. Anderson et al. (2009) previously showed that the bacterial community of different soils did not converge to a similar community structure after metal amendment acknowledging that other factors may also be important in shaping the community. 


\section{Acknowledgements}

This work is financially supported by the Institute for the Promotion of Innovation through Science and Technology in Flanders (IWT-Vlaanderen) and by a post-doctoral mandate (PDMKULeuven). JM thanks the Fund for Scientific Research-Flanders (F.W.O.-Vlaanderen) for a position as postdoctoral researcher. We thank Kristin Coorevits for ICP-OES analysis and Peter Salaets for assistance in the lab.

\section{References}

Akerblom, S., Bååth, E., Bringmark, L., Bringmark, E., 2007. Experimentally induced effects of heavy metal on microbial activity and community structure of forest mor layers. Biology and Fertility of Soils 44, 79-91.

Almås, A.R., Bakken, L.R., Mulder, J., 2004. Changes in tolerance of soil microbial communities in $\mathrm{Zn}$ and $\mathrm{Cd}$ contaminated soils. Soil Biology and Biochemistry 36, 805-813.

Anderson, J.A.H., Hooper, M.J., Zak, J.C., Cox, S.B., 2009. Molecular and functional assessment of bacterial community convergence in metal-amended soils. Microbial Ecology 58, 10-22.

Bååth, E., Frostegård, A., Díaz-Raviña, M., Tunlid, A., 1998. Microbial community-based measurements to estimate heavy metal effects in soil: The use of phospholipid fatty acid patterns and bacterial community tolerance. Ambio 27, 58-61.

Broos, K., Warne, M.S.J., Heemsbergen, D.A., Stevens, D., Barnes, M.B., Correll, R.L., McLaughlin, M.J., 2007. Soil factors controlling the toxicity of copper and zinc to microbial processes in Australian soils. Environmental Toxicology and Chemistry 26, 583-590.

Bruins, M.R., Kapil, S., Oehme, F.W., 2000. Microbial resistance to metals in the environment. Ecotoxicology and Environmental Safety 45, 198-207. 
Díaz-Raviña, M., Bååth, E., 1996. Development of metal tolerance in soil bacterial communities exposed to experimentally increased metal levels. Applied and Environmental Microbiology 62, 2970-2977.

Díaz-Raviña, M., Bååth, E., Frostegård, Å., 1994. Multiple heavy-metal tolerance of soil bacterial communities and its measurement by a thymidine incorporation Technique. Applied and Environmental Microbiology 60, 2238-2247.

Doelman, P., Haanstra, L., 1989. Short-term and long-term effects of heavy-metals on phosphatase-activity in soils - an ecological dose-response model approach. Biology and Fertility of Soils 8, 235-241.

Fait, G., Broos, K., Zrna, S., Lombi, E., Hamon, R., 2006. Tolerance of nitrifying bacteria to copper and nickel. Environmental Toxicology and Chemistry 25, 2000-2005.

Fromin, N., Hamelin, J., Tarnawski, S., Roesti, D., Jourdain-Miserez, K., Forestier, N., TeyssierCuvelle, S., Gillet, F., Aragno, M., Rossi, P., 2002. Statistical analysis of denaturing gel electrophoresis (DGE) fingerprinting patterns. Environmental Microbiology 4, 634-643.

Frostegård, A., Tunlid, A., Bååth, E., 1993. Phospholipid fatty-acid composition, biomass, and activity of microbial communities from 2 soil types experimentally exposed to different heavymetals. Applied and Environmental Microbiology 59, 3605-3617.

Frostegård, A., Tunlid, A., Bååth, E., 1996. Changes in microbial community structure during long-term incubation in two soils experimentally contaminated with metals. Soil Biology and Biochemistry 28, 55-63. 
Giller, K.E., Witter, E., McGrath, S.P., 1998. Toxicity of heavy metals to microorganisms and microbial processes in agricultural soils: A review. Soil Biology and Biochemistry 30, 13891414.

Koops, H.P., Pommerening-Roser, A., 2001. Distribution and ecophysiology of the nitrifying bacteria emphasizing cultured species. FEMS Microbiology Ecology 37, 1-9.

Kumar, S., Tamura, K., Nei, M., 2004. MEGA3: Integrated software for molecular evolutionary genetics analysis and sequence alignment. Briefings in Bioinformatics 5, 150-163.

Mergeay, M., 1991. Towards an understanding of the genetics of bacterial metal resistance. Trends in Biotechnology 9, 17-24.

Mertens, J., Broos, K., Wakelin, S.A., Kowalchuk, G.A., Springael, D., Smolders, E., 2009. Bacteria, not archaea, restore nitrification in a zinc-contaminated soil. ISME Journal 3, 916-923.

Mertens, J., Degryse, F., Springael, D., Smolders, E., 2007. Zinc toxicity to nitrification in soil and soilless culture can be predicted with the same biotic ligand model. Environmental Science \& Technology 41, 2992-2997.

Mertens, J., Springael, D., De Troyer, I., Cheyns, K., Wattiau, P., Smolders, E., 2006. Long-term exposure to elevated zinc concentrations induced structural changes and zinc tolerance of the nitrifying community in soil. Environmental Microbiology 8, 2170-2178.

Mertens, J., Wakelin, S.A., Broos, K., McLaughlin, M.J., Smolders, E., 2010. Extent of copper tolerance and consequences for functional stability of the ammonia-oxidizing community in longterm copper-contaminated soils. Environmental Toxicology and Chemistry 29, 27-37.

Millward, R.N., Klerks, P.L., 2002. Contaminant-adaptation and community tolerance in ecological risk assessment: Introduction. Human and Ecological Risk Assessment 8, 921-932. 
Nies, D.H., 1999. Microbial heavy-metal resistance. Applied Microbiology and Biotechnology $51,730-750$.

Oorts, K., Bronckaers, H., Smolders, E., 2006. Discrepancy of the microbial response to elevated copper between freshly spiked and long-term contaminated soils. Environmental Toxicology and Chemistry 25, 845-853.

Park, S., Ely, R.L., 2008. Genome-wide transcriptional responses of Nitrosomonas europaea to zinc. Archives of Microbiology 189, 541-548.

Ramette, A., 2007. Multivariate analyses in microbial ecology. FEMS Microbiology Ecology 62, 142-160.

Rotthauwe, J.H., Witzel, K.P., Liesack, W., 1997. The ammonia monooxygenase structural gene amoA as a functional marker: molecular fine-scale analysis of natural ammonia-oxidizing populations. Applied and Environmental Microbiology 63, 4704-4712.

Rusk, J.A., Hamon, R.E., Stevens, D.P., McLaughlin, M.J., 2004. Adaptation of soil biological nitrification to heavy metals. Environmental Science \& Technology 38, 3092-3097.

Ruyters, S., Mertens, J., Springael, D., Smolders, E., 2010. Stimulated activity of the soil nitrifying community accelerates community adaptation to $\mathrm{Zn}$ stress. Soil Biology and Biochemistry 42, 766-772.

Ryan, R.P., Ryan, D.J., Dowling, D.N., 2005. Multiple metal resistant transferable phenotypes in bacteria as indicators of soil contamination with heavy metals. Journal of Soils and Sediments 5, 95-100.

Smolders, E., McGrath, S.P., Lombi, E., Karman, C.C., Bernhard, R., Cools, D., Van Den Brande, K., Van Os, B., Walrave, N., 2003. Comparison of toxicity of zinc for soil microbial 
processes between laboratory-contaminated and polluted field soils. Environmental Toxicology and Chemistry 22, 2592-2598.

Stephen, J.R., Kowalchuk, G.A., Bruns, M.A.V., McCaig, A.E., Phillips, C.J., Embley, T.M., Prosser, J.I., 1998. Analysis of beta-subgroup proteobacterial ammonia oxidizer populations in soil by denaturing gradient gel electrophoresis analysis and hierarchical phylogenetic probing. Applied and Environmental Microbiology 64, 2958-2965.

Thompson, J.D., Higgins, D.G., Gibson, T.J., 1994. Clustal-W - Improving the sensitivity of progressive multiple sequence alignment through sequence weighting, position-specific gap penalties and weight matrix choice. Nucleic Acids Research 22, 4673-4680.

Tipping, E., Lofts, S., Lawlor, A.J., 1998. Modelling the chemical speciation of trace metals in the surface waters of the Humber system. Science of the Total Environment 210, 63-77.

Tobor-Kaplon, M.A., Bloem, J., De Ruiter, P.C., 2006. Functional stability of microbial communities from long-term stressed soils to additional disturbance. Environmental Toxicology and Chemistry 25, 1993-1999.

Tobor-Kaplon, M.A., Bloem, J., Romkens, P.F.A.M., De Ruiter, P.C., 2006. Functional stability of microbial communities in contaminated soils near a zinc smelter (Budel, The Netherlands). Ecotoxicology 15, 187-197.

Weng, L.P., Temminghoff, E.J.M., Lofts, S., Tipping, E., Van Riemsdijk, W.H., 2002. Complexation with dissolved organic matter and solubility control of heavy metals in a sandy soil. Environmental Science \& Technology 36, 4804-4810. 
Witter, E., Gong, P., Bååth, E., Marstorp, H., 2000. A study of the structure and metal tolerance of the soil microbial community six years after cessation of sewage sludge applications. Environmental Toxicology and Chemistry 19, 1983-1991.

\section{Supplementary Information}

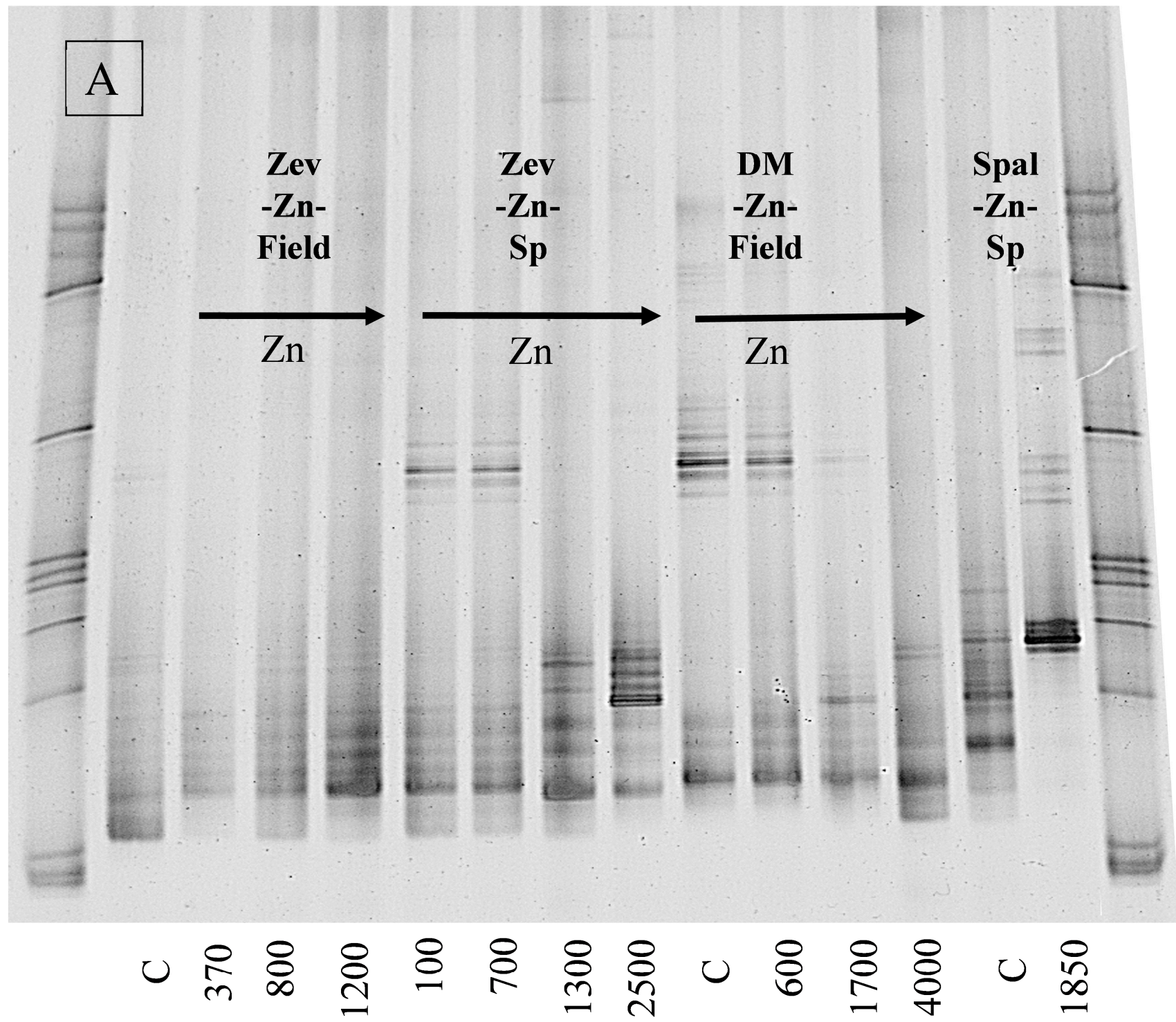




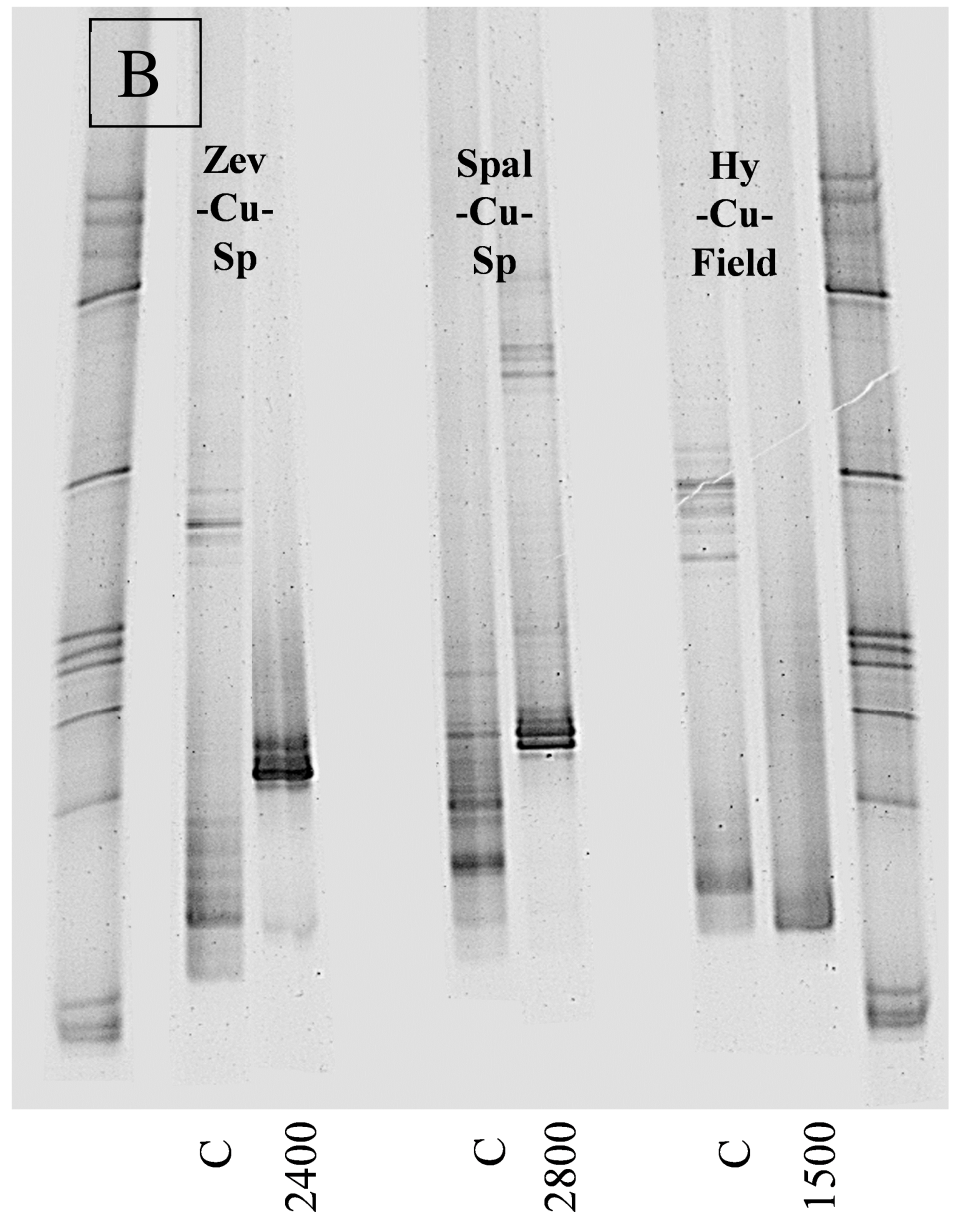

Supplementary Figure 1: amoA AOB DGGE profiles of soil samples with increasing metal contamination. Panel A shows changes of the amoA AOB community upon $\mathrm{Zn}$ contamination and Panel $B$ upon $\mathrm{Cu}$ contamination. Metal concentrations (mg $\left.\mathbf{~ k g}^{-1}\right)$ are given under the DGGE profiles (C: control). 